\title{
Influence of hot water blanching process on nutritional content, microstructure, antioxidant activity and phenolic profile of Cinnamomum porrectum herbal tea
}

\author{
Phornthip Saetan $^{1}$, Worapong Usawakesmanee ${ }^{1 *}$, and Sunisa Siripongvutikorn ${ }^{1}$ \\ ${ }^{1}$ Department of Food Technology, Faculty of Agro-Industry, \\ Prince of Songkla University, Hat Yai, Songkhla 90112, Thailand
}

${ }^{1 *}$ Corresponding Author: Worapong Usawakesmanee, PhD, Department of Food Technology, Faculty of Agro-Industry, Prince of Songkla University, Hat Yai, Songkhla, 90112, Thailand

Submission Date: October 21, 2016, Accepted Date: December 28, 2016, Publication Date: December 30,2016

Citation: Saetan P., UsawakesmaneeW., , and Siripongvutikorn S. Influence of hot water blanching process on nutritional content, microstructure, antioxidant activity and phenolic profile of Cinnamomum porrectum herbal tea. Functional Foods in Health and Disease 2016; 6(12): 836-854

\begin{abstract}
Background: Cinnamomum porrectum leaves, one kind of Cinnamomum family, has recently been used to produce a locally herbal tea. Although C. porrectum essential oil and aqueous extract have been reported to have some biological activities, including antioxidant, antimicrobial, and anti-inflammatory activities, there is no scientific data using the blanching process for the production of herbal tea. Therefore, this experiment aimed to study the effect of hot water blanching before drying process on microstructure, nutrition content of the tea powder, TPC, TFC, antioxidant activities of infusion, as well as the phenolic profile of the extract.
\end{abstract}

Objective: To determine effect of hot water blanching process on nutritional value, microstructure, phenolic profile, and antioxidant activity of the C. porrectum herbal tea.

Methods: The C. porrectum leaves were divided into 2 groups; control (un-treated) and blanched before dried for herbal tea processing. The fresh leaves and the powders of control and blanched leaves were checked for proximate composition and chlorophyll contents, in addition to color value. The powders were determined microstructure by SEM. The infusions were determined to have color value and total extractable phenolic and flavonoid contents, as well as antioxidant activities. The hydrolyzed extracts of freeze dried infusion were subjected to identify phenolic profile by HPLC. 
Results: The blanched tea powder yielded a percentage of fat and protein contents higher than untreated due to easier extraction because of the bigger pore size found in microstructure. Chlorophyll content of blanched was decreased compared with the control sample. However, it was found that blanching could greater maintain green color of both powder and infusion. Additionally, blanching helped increased TPC, TFC extractability, and antioxidant activities in all assays except metal chelating property. Based on retention time and peak profile determined by using HPLC, it was found that both control and treated extracts consisted of similar main phenolic and flavonoid compounds however, only kaempferol was found in un-treated. Moreover, hydrolyzed blanched extract showed a higher intensity of 2 unknown compounds than un-treated. Though un-treated provided a higher intensity of pyrogallol, gallic acid, and cinnamic acid, the blanched exhibited a higher intensity of caffeic acid, protocatechuic acid, $p$-coumaric acid, and rutin.

Conclusion: Blanching before drying expanded pore size of dried leaves, increased yield extractability, maintained color value, chlorophylls and increased TPC and TFC which related to antioxidant activities. Blanched extract provided higher intensity of some phenolic compounds than un-treated.

Keywords: Cinnamomum porrectum, blanching process, SEM, HPLC

\section{BACKGROUND}

Since tea's high health benefit was proven, its consumption around the world has been increasing. Green tea, a non-fermented tea, contains high polyphenolic compounds and many studies have been reported that polyphenolic compounds from green tea leaf extract provided a greater antioxidant activity in biological system, against tumourigenesis and DNA damage than black tea $[1,2]$. With health benefit improving, both tea and herbal tea are more widely commercialized and consumed [3].

Cinnamomum genus belongs to the family Lauraceae comprises about 250 species are found in India, China, Srilanka and Australia. Leaves of Cinnamomum plants are used extensively as spices in food or to produce essential oils. The crushed leaf provides a hot sensation and emits a spicy odor. Cinnamomum porrectum (synonym Cinnamomum parthenoxylon) or Thai name Theptharo, a native plant grown in south of Thailand and Asian elsewhere has been extensively used in food and also folk medicine, particularly in India [4, 5, 6]. Pukdeekumjorn et al. [7] reported that this plant wood extracted by water and $95 \%$ of ethanol showed TPC values as $264.06 \pm 5.77$ and $118.18 \pm 1.26 \mathrm{mg} \mathrm{GAE} / 100 \mathrm{~g}$ and expressed DPPH activity based on $\mathrm{EC}_{50}$ values as $7.92 \pm 0.20$ and $13.18 \pm 3.95 \mu \mathrm{g} / \mathrm{ml}$, respectively. Furthermore, it significantly provided pharmacological efficacy such as anti-inflammation, antimicrobial, antifungal, antioxidant, and antidiabetic properties $[7,8,9]$. 
Additionally, as supported from a marketing survey, Theptharo tea is only available through local markets market. In fact, essential oils of $C$. porrectum have been reported to have promising antioxidant activity, while the water extract of this plant provided some antioxidant, antiinflammation, and antimicrobial activities. However, there is no scientific data using the blanching process for producing the $C$. porrectum herbal tea. Therefore, this experiment aimed to study the effect of hot water blanching before drying process on microstructure, nutritional content of herbal tea powder, TPC, TFC, antioxidant activities of infusion, as well as phenolic profile of hydrolyzed extract.

\section{MATERIALS AND METHODS}

\section{Materials}

\section{Plant material and herbal tea preparation}

The developing leaves or intermediate stage with light green to green color and flexible stalks were collected during May to August 2015 from Technology Research Centre of Forestry sector, Songkhla. In order to preserve their original quality, leaves were stored in a refrigerator at $4{ }^{\circ} \mathrm{C}$ and used within $2 \mathrm{~d}$. From the preliminary test, it was discovered that the leaves blanched with hot water at $100{ }^{\circ} \mathrm{C}$ provided the better extractability in both phenolic compounds determined by FolinCiocalteau reagent and antioxidant activity determined by DPPH and ABTS scavenging activity. Therefore, the leaves were prepared as previously studied showed in Figure 1.

\section{Herbal tea infusion preparation}

The powder $(0.5 \mathrm{~g})$ of un-treated (control) and blanched sample was extracted with $100 \mathrm{ml} \mathrm{DI}$ water at $95{ }^{\circ} \mathrm{C}$ for $10 \mathrm{~min}$ by using water bath before filtered and cooled down the filtrate in water to reached room temperature $28-30{ }^{\circ} \mathrm{C}$ and kept in refrigerator at $4{ }^{\circ} \mathrm{C}$ before analysis within 1 day. The both infusions were subjected to freeze drying and kept in desiccator for HPLC analysis.

\section{Methods}

\section{Proximate composition determination}

Proximate composition of un-treated and blanched C. porrectum herbal tea including moisture, protein, fat, fiber, ash, and carbohydrate contents were analyzed following the AOAC [10].

\section{Structure of powder determination by scanning electron microscopy (SEM)}

The surface morphology of the $C$. porrectum non-pretreated and pre-treated powder were investigated using a scanning electron microscope, Quanta 400 (FEI, Czech Republic) at high voltage $20.00 \mathrm{kV}$ at $500 \mathrm{x}$ magnification. 


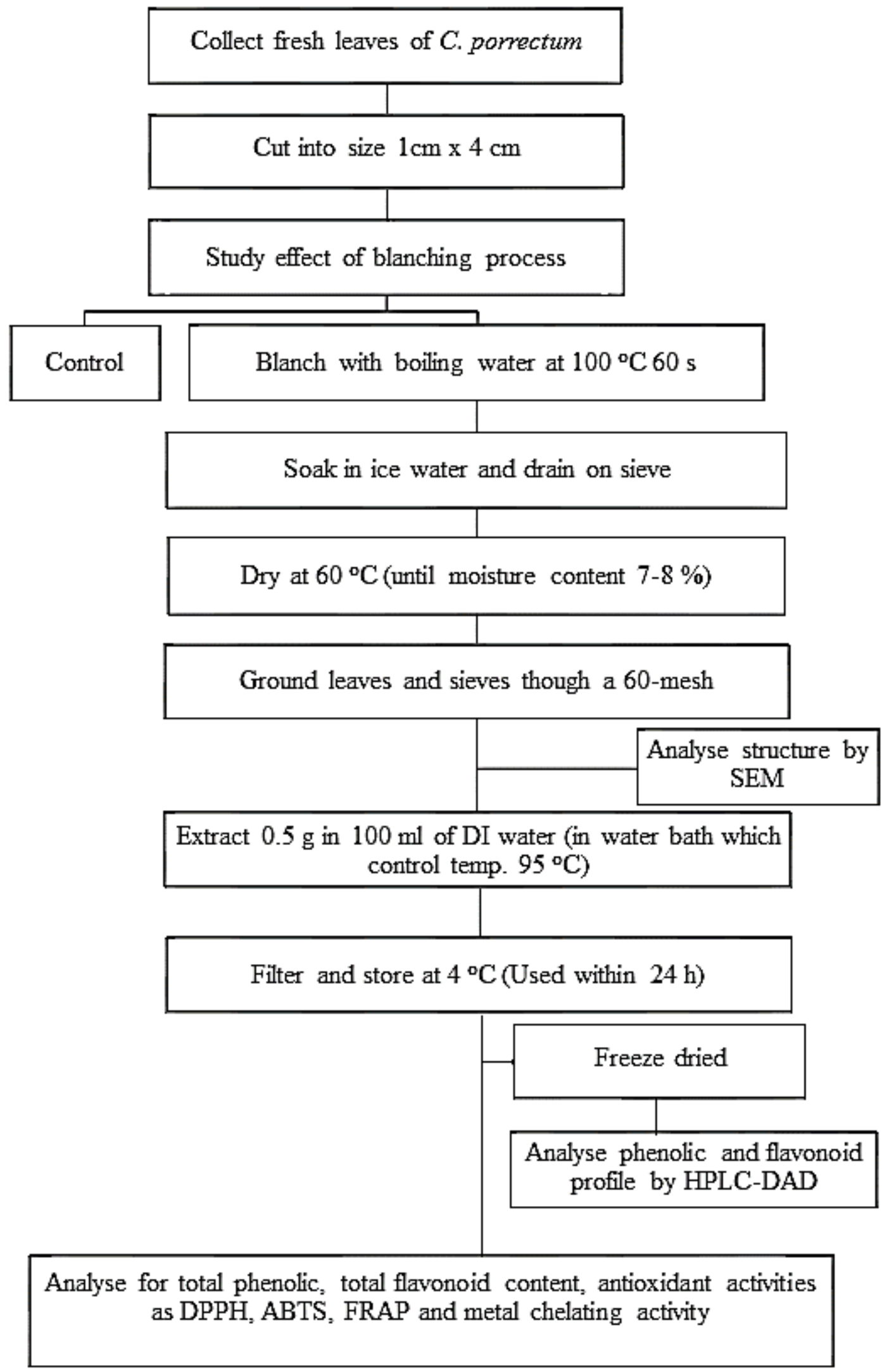

Figure 1. C. porrectum herbal tea preparations and analyses. 


\section{Total chlorophylls and carotenoid content analysis}

Chlorophyll and carotenoid content of pre-treated of $C$. porrectum leaves and powder were analyzed following the AOAC [11]. Briefly, 0.5-1.0 $\mathrm{g}$ of the fresh, pre-treated leaves (before drying process) and powder were separately added with $0.1 \mathrm{~g}$ of $\mathrm{CaCO}_{3}$, followed by a pinch of purified acid sand and $20 \mathrm{ml}$ of $80 \%$ acetone, then ground in a motor at ambient temperature for 5-10 min before taken to filter thought a Whatman No.1 filter paper. The residue was re-extracted with $5 \mathrm{ml}$ of $80 \%$ acetone until tissue did not show any greenish color while solvent was colorless. All filtrated solutions of each sample were pooled and added with $\mathrm{Na}_{2} \mathrm{SO}_{4}$ anhydrous to remove excess water, and then filtered again before adjusted the final volume to $100 \mathrm{ml}$ with $100 \%$ acetone.

Total chlorophyll, chlorophyll a, b and carotenoid were determined spectrophotometrically at 470, 649 and $665 \mathrm{~nm}$. The components were calculated as followed equation:

$\mathrm{C}_{\mathrm{a}}(\mathrm{mg} / \mathrm{g}$ of dry weight $)=\left(12.7 \mathrm{~A}_{665}-2.69\right.$
$\mathrm{C}_{\mathrm{b}}(\mathrm{mg} / \mathrm{g}$ of dry weight $)=\left(22.9 \mathrm{~A}_{649}-4\right.$
$\mathrm{C}_{\mathrm{a}+\mathrm{b}}(\mathrm{mg} / \mathrm{g}$ of dry weight $)=\left(20.2 \mathrm{~A}_{649}\right.$
$\mathrm{C}_{\mathrm{a}+\mathrm{c}}(\mathrm{mg} / \mathrm{g}$ of dry weight $)=\left(\left(1000 \mathrm{~A}_{470}\right.\right.$
When;
$\mathrm{A}=\quad$ Absorbance $(\mathrm{nm})$
$\mathrm{v}=\quad$ Total volume of extract $(\mathrm{ml})$
$\mathrm{w}=\quad$ Weight of sample $(\mathrm{g})$
$\mathrm{C}_{\mathrm{a}}=\quad$ Chlorophyll a
$\mathrm{C}_{\mathrm{b}}=\quad$ Chlorophyll b
$\mathrm{C}_{\mathrm{a}+\mathrm{b}}=\quad$ Total chlorophyll
$\mathrm{C}_{\mathrm{a}+\mathrm{c}}=\quad$ Carotenoid

\section{Color value}

A colorimeter was used for measuring the color quality determined as Hunter value L* (brightness, $100=$ white, $0=$ black), a* (+: red, - : green), b* (+: yellow, - : blue) and $-\mathrm{a} / \mathrm{b}$ expressed as green, yellow color of pre-treated of $C$. porrectum leaves, powder and herbal tea infusion.

\section{Analysis of total extractable phenolic content and total extractable flavonoid content}

Total extractable phenolic content of all infusions were determined by using the Folin-Ciocalteau reagent. Sample, $50 \mu$, was introduced into 96-well plate followed by adding of $150 \mu 1$ of FolinCiocalteu's reagent (10 times dilution) and $120 \mu \mathrm{l}$ of sodium carbonate $(7.5 \% \mathrm{w} / \mathrm{v})$. The plates were allowed to stand for $30 \mathrm{~min}$ in dark before subjected to determine absorbance at $765 \mathrm{~nm}$. Standard curve was made by using gallic acid at concentration $20-100 \mu \mathrm{g} / \mathrm{ml}$, pyrogallol as $10-80$ $\mu \mathrm{g} / \mathrm{ml}, p$-coumaric acid at 20-200 $\mu \mathrm{g} / \mathrm{ml}$, Trolox at 100-600 $\mu \mathrm{g} / \mathrm{ml}$ and catechin at 20-100 $\mu \mathrm{g} / \mathrm{ml}$ and the results were expressed as $\mathrm{mg}$ of each standard equivalent/ $\mathrm{g}$ sample. Total extractable flavonoid content of the infusions was determined by using the aluminum chloride colorimetric method. Briefly, $25 \mu \mathrm{l}$ of the infusion was added into the 96 -well plate containing $100 \mu \mathrm{l}$ of water. At zero time, $10 \mu \mathrm{l}$ of $5 \% \mathrm{NaNO}_{2}$ was added and stand for 5 min before $15 \mu \mathrm{l}$ of $10 \% \mathrm{AlCl}_{3}$ was mixed further. After that, $50 \mu \mathrm{l}$ of $1 \mathrm{M} \mathrm{NaOH}$ was added into the mixture and the volume was made up to $250 \mu \mathrm{l}$ with water. An absorbance was measured at $510 \mathrm{~nm}$. Catechin was used as 
standard with concentration 100-600 $\mu \mathrm{g} / \mathrm{ml}$ and the results were expressed as $\mathrm{mg}$ catechin equivalent (mg CE/g sample).

\section{Analysis of antioxidant activity \\ DPPH radical-scavenging activity}

DPPH radical scavenging activity was determined as described by Wu et al. [12]. Briefly, sample $150 \mu$, was added with $150 \mu \mathrm{l}$ of $0.15 \mathrm{mM} \mathrm{2,2}$-diphenyl-1-picyl hydrazyl (DPPH) which dissolved in methanol. The mixture was mixed well in 96- well plates and allowed to stand at ambient temperature $\left(28 \pm 2{ }^{\circ} \mathrm{C}\right)$ in dark for $30 \mathrm{~min}$. The absorbance of the resulting solution was measured at $517 \mathrm{~nm}$ using a spectrophotometer. Sample blank was prepared in the same manner except methanol was used instead of DPPH solution. The plates were allowed to stand for $30 \mathrm{~min}$ in dark before subjected to determine absorbance at $765 \mathrm{~nm}$. Standard curve was made by using gallic acid at concentration $0.5-2.0 \mu \mathrm{g} / \mathrm{ml}$, pyrogallol at $0.1-1.6 \mu \mathrm{g} / \mathrm{ml}, p$-coumaric acid at 100$1000 \mu \mathrm{g} / \mathrm{ml}$ and Trolox at $5-25 \mu \mathrm{g} / \mathrm{ml}$ and the results were expressed as $\mathrm{mg}$ of each standard equivalent/g sample.

\section{ABTS radical-scavenging activity}

ABTS radical-scavenging activity was evaluated with the following method of Arnao et al. [13]. $7.4 \mathrm{mM}$ ABTS solution and $2.6 \mathrm{mM}$ potassium persulphate solution were prepared as stock solutions. The working solution was prepared by mixing the two stock solutions in equal quantities. The mixture was allowed to react for $12 \mathrm{~h}$ at ambient temperature in the dark. The mixed solution was diluted by mixing $1 \mathrm{ml}$ of ABTS solution with $50 \mathrm{ml}$ of water in order to obtain an absorbance of $1.1 \pm 0.02$ units at $734 \mathrm{~nm}$. Briefly, sample, $15 \mu 1$, as mixed with $285 \mu 1$ of ABTS solution and the mixture was left at ambient temperature for $2 \mathrm{~h}$ in dark. The absorbance was measured at $734 \mathrm{~nm}$ using a micro plate spectrophotometer. Sample blank was prepared in the same manner by using water instead of ABTS solution. Standard curve was made by using gallic acid at concentration 2-20 $\mu \mathrm{g} / \mathrm{ml}$, pyrogallol at $1-20 \mu \mathrm{g} / \mathrm{ml}, p$-coumaric acid at $5-50 \mu \mathrm{g} / \mathrm{ml}$ and Trolox at 50-125 $\mu \mathrm{g} / \mathrm{ml}$ and the results were expressed as $\mathrm{mg}$ of each standard equivalent/g sample.

\section{FRAP (ferric reducing antioxidant power)}

FRAP was assayed according to Benzie and Strain [14]. $300 \mathrm{mM}$ acetate buffer (pH 3.6), $10 \mathrm{mM}$ TPTZ (2, 4, 6- tripyridyl-s-triazine) solution dissolved in $40 \mathrm{mM} \mathrm{HCl}$, and $20 \mathrm{mM} \mathrm{FeCl} 3.6 \mathrm{H}_{2} \mathrm{O}$ solution were made for stock solutions. A working solution was prepared freshly by mixing $25 \mathrm{ml}$ of acetate buffer, $2.5 \mathrm{ml}$ of TPTZ solution and $2.5 \mathrm{ml}$ of $\mathrm{FeCl}_{3} \cdot 6 \mathrm{H}_{2} \mathrm{O}$ solution. The mixed solution was incubated at $37{ }^{\circ} \mathrm{C}$ for $30 \mathrm{~min}$ in incubator and referred as FRAP solution. Later, sample, 15 $\mu 1$, was mixed with $285 \mu 1$ of FRAP solution and kept at ambient temperature for 30 min in dark. The ferrous tripyridyltriazine complex (blue colored product) was measured by reading the absorbance at $593 \mathrm{~nm}$. Sample blank was prepared by omitting $\mathrm{FeCl}_{3}$ from FRAP solution and distilled water was used instead. Standard curve was made by using gallic acid at concentration 2$20 \mu \mathrm{g} / \mathrm{ml}$, pyrogallol at 1-25 $\mu \mathrm{g} / \mathrm{ml}, p$-coumaric acid at 50-200 $\mu \mathrm{g} / \mathrm{ml}$ and Trolox at $25-40 \mu \mathrm{g} / \mathrm{ml}$ and the results were expressed as $\mathrm{mg}$ of each standard equivalent/g sample. 


\section{Metal chelating activity on ferrous ions $\left(\mathrm{Fe}^{2+}\right)$}

The chelating activity towards $\mathrm{Fe}^{2+}$ was measured by the method of Boyer and McCleary [15]. Briefly, $1.0 \mathrm{ml}$ of sample was mixed with $0.1 \mathrm{ml}$ of $0.2 \mathrm{mM} \mathrm{FeCl}_{2}$. The reaction mixture was allowed to stand for $10 \mathrm{~min}$ at ambient temperature and then added with $0.2 \mathrm{ml}$ of $5 \mathrm{mM}$ ferrozine. The mixture was allowed to stand for more $10 \mathrm{~min}$ at ambient temperature. The absorbance was then read at $562 \mathrm{~nm}$. The blank was prepared in the same manner by using distilled water instead of the sample. The sample blank at each concentration, $\mathrm{FeCl}_{2}$ solution was excluded and distilled water was used instead. The standard curve was made by using EDTA ranking from 10-50 $\mu \mathrm{g} / \mathrm{ml}$. The activity was expressed as mg EDTA equivalent/g sample.

\section{Analysis of phenolic and flavonoid profile by HPLC-PDA}

Determination of phenolic and flavonoid compound profile of the non-treated and pre-treated leaves of $C$. porrectum were performed using HPLC (High Performance Liquid Chromatography, Waters 717 Autosampler-Pump 600-PDA996) equipped with photo diode array detector (PDA). Briefly, $1.0 \mathrm{mg}$ of freeze dried form of the extracts were hydrolyzed by $6 \mathrm{~N} \mathrm{HCl}$ at ratio 1:5 (w/v) at $70{ }^{\circ} \mathrm{C}$ for $3 \mathrm{~h}$. The hydrolyzed sample was filtered through syringe filter nylon with $0.22 \mu \mathrm{m}$ pore size before injected into HPLC. Separation of phenolic and flavonoid compounds were achieved using commercially available reverse-phase Purosher ${ }^{\circledR}$ STAR RP-18 endcapped $5 \mu \mathrm{m}$ LiChroCART ${ }^{\circledR}$ 250-4.6 and gradient mobile phase consisted of 1.0\% trifluoroacitic acid (TFA) in water $(\mathrm{v} / \mathrm{v}), \mathrm{pH} 1.8$ (eluent $\mathrm{A}$ ) and acetonitrile (ACN) (eluent $\mathrm{B})$. The gradient condition was set up as followed: 0-5 min, 5\% B; 5-15 min, 10\% B; $20 \mathrm{~min}, 15 \% \mathrm{~B} ; 30-35,25 \% \mathrm{~B} ; 40 \mathrm{~min} 50 \%$ $\mathrm{B}$; $50 \mathrm{~min} 80 \% \mathrm{~B}$; $51-60 \mathrm{~min}, 100 \%$ A. Elution was performed at a solvent flow rate of $1.0 \mathrm{ml} / \mathrm{min}$ and injection volume $10 \mu \mathrm{l}$. Detection was accomplished with a PDA and chromatograms were recorded at $280 \mathrm{~nm}$. The amount of individual phenolic acid and flavonoid compound in the extracts were determined by using a standard curve of phenolic acid and flavonoid standards (0.5$20 \mathrm{mg} / \mathrm{l}$ for 16 standard including gallic acid, protocatechuic acid, catechin, chlorogenic acid, vanillic acid, caffeic acid, syringic acid, rutin, $p$-coumaric acid, ferulic acid, quercetin, rosmarinic acid, quercitrin, cinnamic acid, apigenin, and kaempferol; 1-40 mg/l for tannic acid and 5-200 mg/l for pyrogallol) (x-axis) and the peak height of the standard (y-axis).

\section{Statistical analyses}

The data was subjected to Analysis of Variance (ANOVA) and the differences between means were evaluated by paired sample and Duncan's Multiple Range Test

\section{RESULTS AND DISCUSSION \\ Proximate composition}

There was no statistical significant difference in total protein content of both control and blanched sample (Table 1). This result was in agreement with Song et al. [16], who reported that total amino acid and protein in blanched vegetable soybeans (Glycine max (L.) Merrill) did not change when blanching at $80{ }^{\circ} \mathrm{C}$ for $30 \mathrm{~min}, 90^{\circ} \mathrm{C}$ for $20 \mathrm{~min}$, and $100{ }^{\circ} \mathrm{C}$ for $10 \mathrm{~min}$. However, Cheftel et al. [17] reported that the solubility of proteins when blanching at $90{ }^{\circ} \mathrm{C}$ and $100{ }^{\circ} \mathrm{C}$ was lower than that of native proteins because of the leaching effect [16]. The result of total ash content being significantly decreased by blanching process $(\mathrm{p}<0.05)$ may be due to possible leaching effect into 
blanching water. Dugo et al. [18] reported the loss of minerals during the boiling of vegetables and tubers including carrot, bamboo shoot, broccoli, potato, and cocoyam due to the leaching effect [19].

Though blanched powder was significantly higher in fat and crude fiber content $(\mathrm{p}<0.05)$, untreated sample contained higher ash content as shown in Table 1. It pointed out that blanching processing significantly liberated fat and crude fiber content. This may be due to structure of plant tissue was opened and loosen through $\beta$-sheet destruction during blanching process [20] as explained in Figure 2. Ando et al. [21] reported that the pectins in the middle lamella were leached away thereafter, adhesion of the cell walls was weakened, and the tissue was markedly softened [20]. Furthermore, the blanching process can denature the proteins in cell walls and make the porosity of membranes. The higher porosity increased permeability of cell walls and improved solvent diffusivity, resulting in an increase of yield extractability [22, 23].

Table 1. Proximate composition of un-treated and blanched C. porrectum

\begin{tabular}{llcc}
\hline & Compositions (\%) & Un-treated & Blanched \\
\hline Fresh leaves & Moisture content (\%) & \multicolumn{2}{c}{$60.87 \pm 0.54^{\mathrm{a}}$} \\
Powder & Moisture content (\%) & $3.64 \pm 0.23^{\mathrm{a}}$ & $2.48 \pm 0.13^{\mathrm{b}}$ \\
(dry matter: DM) & Ash (\%) & $4.63 \pm 0.05^{\mathrm{a}}$ & $4.37 \pm 0.05^{\mathrm{b}}$ \\
& Protein (\%) & $8.83 \pm 0.08^{\mathrm{a}}$ & $8.86 \pm 0.09^{\mathrm{a}}$ \\
& Fat (\%) & $2.41 \pm 0.07^{\mathrm{b}}$ & $3.42 \pm 0.19^{\mathrm{a}}$ \\
& Carbohydrate (\%) & $80.49 \pm 0.20^{\mathrm{b}}$ & $81.03 \pm 0.22^{\mathrm{a}}$ \\
& Fiber (\%) & $5.87 \pm 0.56^{\mathrm{b}}$ & $6.55 \pm 0.15^{\mathrm{a}}$ \\
\hline
\end{tabular}

Each value was expressed as the mean \pm standard deviation $(\mathrm{n}=3)$.

Different little letters $(a-b)$ in the same row indicate significant differences $(\mathrm{p}<0.05)$ by compared paired sample.

Structure of $\boldsymbol{C}$. porrectum herbal tea powder determined by scanning electron microscopy The microstructure of un-treated and blanched at $100{ }^{\circ} \mathrm{C}$ for $60 \mathrm{~s}$ is shown in Figure 3 . The cross sectional microstructure of blanched powder at magnification 500x (Figure 3 A 2 and B2) showed a wider porosity than un-treated due to weakening and/ or decreasing of cell wall structure components such as cellulose, hemicellulose, lignin, and structure of protein [18, 19, 24]. Erbay and Icier [25] reported that the drying process with high temperature and long time can induce a case hardening or packing characteristic of fresh leaves surface leading to a decreasing of vaporization in olive leaves. In this present work, the blanched powder had less hardening than un-treated powder (Figure $3 \mathrm{~A} 1$ and B1). This pointed out that blanching induced loose structure leading to easier water vaporization during drying step [26]. Additionally, blanched powder showed a lower moisture content than un-treated powder $(2.48 \pm 0.13 \%$ and $3.64 \pm 0.23 \%$, respectively) which confirmed that blanching helped reduce moisture content in dried product during drying process. 


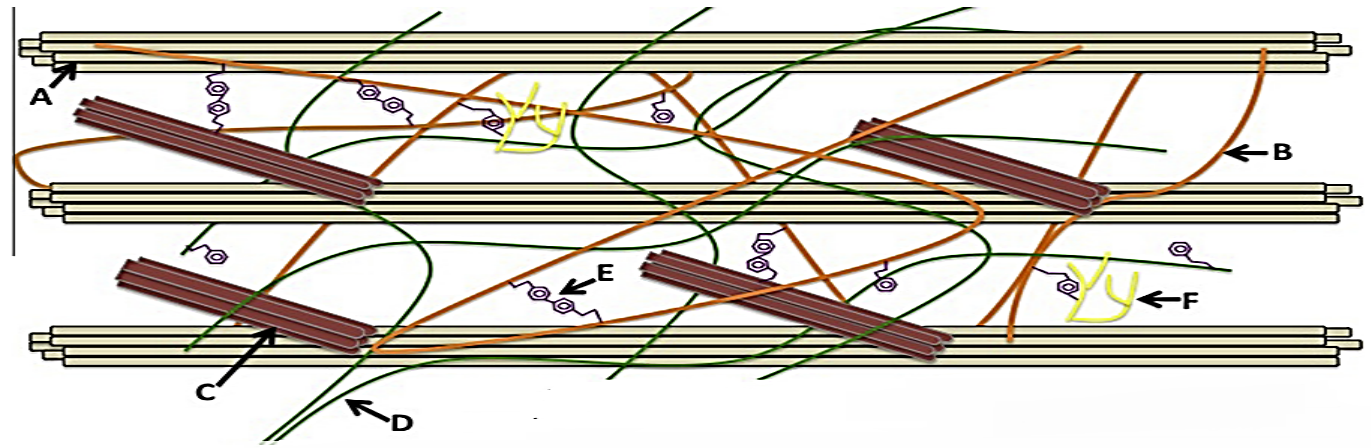

Figure 2. Primary cell wall structure of plant material and cross-linking between structural components and phenolic compounds. (A) Cellulose, (B) Hemicellulose, (C) Structural proteins, (D) Phenolic acids, (F) Lignin.

Source: Acosta-Estrada et al. [24].

Covalent bond of phenolic compounds to cell wall structural components

\begin{tabular}{lll}
\hline Link & Cell wall structure component & Phenolic reactive group \\
\hline Ether & Lignin & Hydroxyl groups in the aromatic ring \\
Ester & Structural carbohydrates and proteins & Carboxylic group \\
\hline
\end{tabular}

$1000 X$
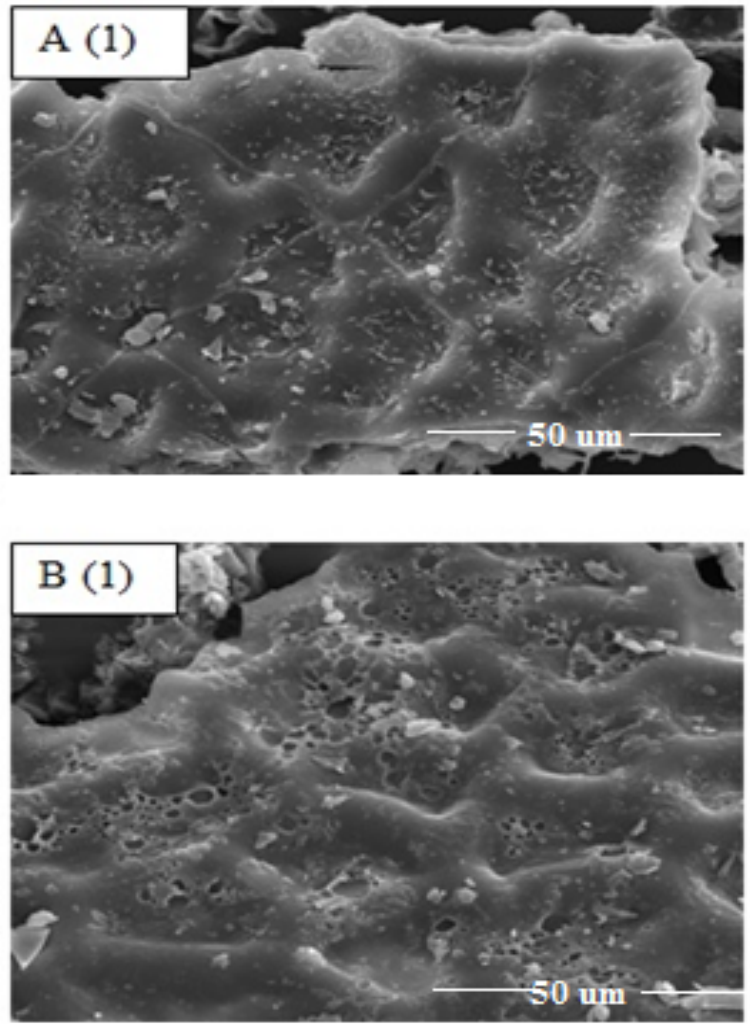

$500 X$
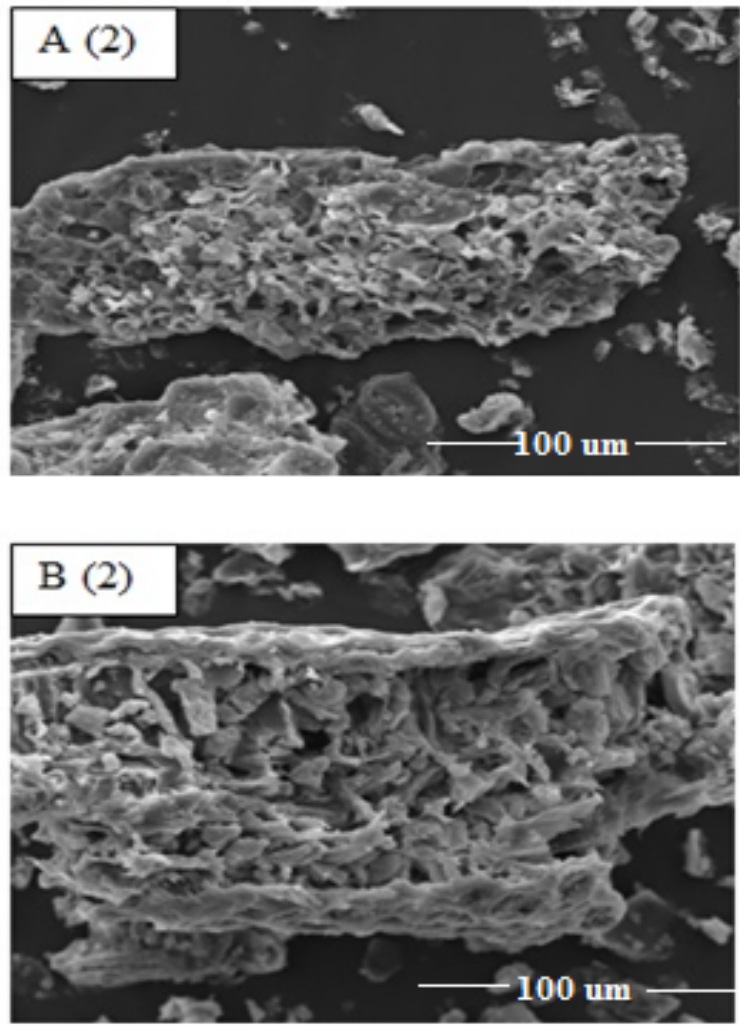

Figure 3. Scanning electron micrographs of un-treated (a) and blanched herbal tea powder (b), remark (1) top view and (2) cross section of powder. 


\section{Total chlorophylls and carotenoid content}

It was discovered that the blanching process significantly reduced total chlorophyll, chlorophyll a, b, and carotenoid when compared with un-blanched sample (Table 2). This may due to 2 reasons; (1) blanching treatment degraded chlorophyll and converted to be pheophytin [27] and (2) during blanching process pronounced more leaching effect particularly chlorophyll [28]. Percentage loss of chlorophyll $a$ and $b$ from blanched leaves and un-blanched leaves were $5.55 \pm 0.19$ and $4.86 \pm 0.07$ respectively. Furthermore, it was found that the retaining of chlorophyll b content was higher than chlorophyll a because of higher thermal stability of chlorophyll b [29]. However, it was also discovered that percentage loss of chlorophyll a and total chlorophyll in the powder obtaining from blanched sample was significantly lower than those of un-blanched powder. This possibly explained the more chlorophyll degradation by chlorophyllase enzyme and heating temperature during drying step of un-blanched sample. In fact, drying process time of blanched and un-treated sample to bring the moisture content down to $2-3 \%$ were 7 and $10 \mathrm{~h}$ respectively. It confirmed that blanching step reduced drying process afterward. Erge et al. [28] reported that optimum temperature of chlorophyllase and other enzymes aid to senescence in vegetables ranged between $60{ }^{\circ} \mathrm{C}$ and $82.2{ }^{\circ} \mathrm{C}$. It pointed out that to preserve chlorophyll content which related to color quality and other functional property, blanching process is still essential to destroy various enzyme including chlorophyllase and polyphenoloxidase. During drying step, chlorophyll b was greater changed to pheophytin $\mathrm{b}$ than chlorophyll a changed to pheophytin $\mathrm{b}$ [28].

A higher loss of carotenoid content was found in blanched sample. Cui et al. [30] reported that carotenoid degradation depended on high temperature due to oxidation reaction can cause isomerization and convert trans-form to cis-carotenoid form leading to less intensity of carotenoid color ranging from yellow-orange.

\section{Color value}

$a^{*}$ value of blanched leaves was higher than that of un-treated leaves (Table 3 ). It indicated that green chlorophyll was converted to olive green pheophytins via the loss of magnesium and replaced with two hydrogen ions as mentioned above [28]. Additionally, the $-\mathrm{a}^{*} / \mathrm{b}^{*}$ ratio which expressed the conversion of green color to yellow color of un-treated was higher $(0.31 \pm 3.23)$ than that of blanched sample $(0.22 \pm 3.05)$.

The powder obtained from the un-treated sample showed a lower $-\mathrm{a}^{*}$ value than blanched might be due to chlorophyllide compound as a result of chlorophyllase activity [31]. On the other hand, the powder of the blanched sample exhibited olive green-yellow color of pheophytin because of magnesium lost in chlorophyll molecule during blanching process $[28,32]$. The $-\mathrm{a}^{*} / \mathrm{b}^{*}$ ratio of un-treated powder was higher than that of blanched powder (Table 3 ).

Although, color of blanched leaves and powder of them seemed to be more yellow or less green, the herbal tea infusion was more greenness compared with un-blanched sample. It pointed out that higher chlorophyll content in the powder (Table 2) played a key role for greenness in the tea infusion. Additionally, the result also showed that using only color value of $a^{*}, b^{*}$ and $-a^{*} / b^{*}$ of dried or powder herbal tea may not provide a good reflection of entire tea infusion. 
Table 2. Total chlorophylls and carotenoid content of un-treated and blanched C. porrectum

\begin{tabular}{|c|c|c|c|c|c|c|c|}
\hline \multirow{2}{*}{ Content } & \multicolumn{2}{|c|}{$\begin{array}{l}\begin{array}{l}\text { Fresh leaves } \\
\text { (dried basis) }\end{array} \\
\end{array}$} & \multirow{2}{*}{$\begin{array}{c}\text { Loss during } \\
\text { blanching } \\
\text { process (\%) }\end{array}$} & \multicolumn{2}{|c|}{$\begin{array}{c}\begin{array}{c}\text { Powder } \\
\text { (dried basis) }\end{array} \\
\end{array}$} & \multicolumn{2}{|c|}{$\begin{array}{c}\text { Loss during } \\
\text { drying process }(\%)\end{array}$} \\
\hline & Un-treated & Blanched & & Un-treated & Blanched & Un-treated & Blanched \\
\hline Chlorophyll a & $2.62 \pm 0.01^{\mathrm{a}}$ & $2.47 \pm 0.01^{\mathrm{b}}$ & $5.55 \pm 0.19$ & $0.54 \pm 0.01^{\mathrm{b}}$ & $0.99 \pm 0.02^{\mathrm{a}}$ & $79.31 \pm 0.51^{\mathrm{a}}$ & $59.92 \pm 0.7^{\mathrm{b}}$ \\
\hline Chlorophyll b & $2.11 \pm 0.01^{\mathrm{a}}$ & $2.01 \pm 0.01^{\mathrm{b}}$ & $4.86 \pm 0.07$ & $0.58 \pm 0.01^{\mathrm{a}}$ & $0.51 \pm 0.04^{\mathrm{a}}$ & $72.38 \pm 0.70^{\mathrm{a}}$ & $74.56 \pm 1.9^{\mathrm{a}}$ \\
\hline Total chlorophyll & $4.83 \pm 0.01^{\mathrm{a}}$ & $4.57 \pm 0.01^{\mathrm{b}}$ & $5.25 \pm 0.13$ & $1.15 \pm 0.01^{\mathrm{b}}$ & $1.53 \pm 0.04^{\mathrm{a}}$ & $75.88 \pm 0.04^{\mathrm{a}}$ & $66.13 \pm 1.0^{\mathrm{b}}$ \\
\hline Carotenoid & $0.99 \pm 0.01^{\mathrm{a}}$ & $0.89 \pm 0.01^{\mathrm{b}}$ & $10.04 \pm 0.36$ & $0.45 \pm 0.03^{\mathrm{a}}$ & $0.31 \pm 0.01^{\mathrm{b}}$ & $54.99 \pm 2.76^{\mathrm{b}}$ & $65.55 \pm 0.9^{\mathrm{a}}$ \\
\hline
\end{tabular}

Each value was expressed as the mean \pm standard deviation $(n=3)$. Different little letters $(a-b)$ in the same row (fresh leaves and powder) indicate significant differences $(\mathrm{p}<0.05)$.

Table 3. Color value of un-treated and blanched C. porrectum

\begin{tabular}{ccccccc}
\hline \multirow{2}{*}{ Content } & \multicolumn{2}{c}{ Fresh leaves } & \multicolumn{2}{c}{ Powder } & \multicolumn{2}{c}{ Infusion } \\
\cline { 2 - 7 } & Un-treated & Blanched & Un-treated & Blanched & Un-treated & Blanched \\
\hline $\mathrm{L}^{*}$ & $27.59 \pm 2.79^{\mathrm{a}}$ & $21.53 \pm 3.46^{\mathrm{b}}$ & $46.16 \pm 0.12^{\mathrm{b}}$ & $49.77 \pm 0.79^{\mathrm{a}}$ & $33.59 \pm 0.35$ & $35.80 \pm 0.04^{\mathrm{a}}$ \\
$\mathrm{a}^{*}$ & $-5.51 \pm 2.86^{\mathrm{a}}$ & $-3.77 \pm 2.50^{\mathrm{a}}$ & $-1.65 \pm 0.10^{\mathrm{b}}$ & $1.42 \pm 0.10^{\mathrm{a}}$ & $1.10 \pm 0.07^{\mathrm{a}}$ & $-0.85 \pm 0.05^{\mathrm{b}}$ \\
$\mathrm{b}^{*}$ & $17.31 \pm 3.61^{\mathrm{a}}$ & $17.31 \pm 3.61^{\mathrm{a}}$ & $25.57 \pm 0.18^{\mathrm{b}}$ & $30.93 \pm 0.22^{\mathrm{a}}$ & $22.25 \pm 0.09^{\mathrm{a}}$ & $13.81 \pm 0.09^{\mathrm{b}}$ \\
$\mathrm{-a}^{*} / \mathrm{b}^{*}$ & $0.31 \pm 3.23^{\mathrm{a}}$ & $0.22 \pm 3.05^{\mathrm{a}}$ & $0.06 \pm 0.14^{\mathrm{a}}$ & $-0.04 \pm 0.16^{\mathrm{b}}$ & $-0.05 \pm 0.06^{\mathrm{b}}$ & $0.06 \pm 0.05^{\mathrm{a}}$ \\
\hline
\end{tabular}

Each value was expressed as the mean \pm standard deviation $(n=5)$. Different little letters $(a-b)$ in the same row (fresh leaves, powder and infusion) indicate significant differences $(\mathrm{p}<0.05)$

\section{Total extractable phenolic, flavonoid content and antioxidant activity}

Generally, phenolic compounds exist in three forms including free, conjugated, and bound. Free and conjugated phenolics are both soluble, whereas bound phenolics are insoluble. The major difference between free and conjugated phenolics is that the conjugated ones are usually esterified to sugars or other compounds with low molecular mass [33, 34], while bound phenolics are covalently bound with cell wall structural components, such as cellulose and proteins [34, 35]. TPC of un-treated herbal tea $(57.07 \pm 1.45 \mathrm{mg}$ GAE/ $\mathrm{g} \mathrm{DB})$ was lower than that of blanched herbal tea $(66.25 \pm 0.89 \mathrm{mg} \mathrm{GAE} / \mathrm{g} \mathrm{DB})$. These results indicated that blanched process increased the content of TPC up to $16.08 \%$ might be due to blanching treatment helped to open cell structure and liberate bound form of phenolics to free form. Not only extractable phenolic compounds but also TFC were increased up to $20.56 \%$ in blanched herbal tea extract.

The result showed that pyrogallol expressed the highest ability to react with Folin-Ciocateu's reagent followed by gallic acid, $p$-coumaric acid, and trolox respectively (Table 4). The results suggested that pyrogallol was the best reference substance to exhibit $\mathrm{H}^{+}$donor, electron transfer and or both abilities, due to the highest number of hydroxyl groups being proportional to its small molar mass. In fact, pyrogallol has only one ring and no other substituted groups so that make less influenced by electronic interactions such as steric or resonance effects [36]. Therefore, pyrogallol not only showed highest of TPC but also showed highest antioxidant activities when determined as ABTS and FRAP assay, but not DPPH assay which gallic acid expressed higher value compared with pyrogallol this result confirmed that main bioactive compounds responded to high polar compounds due to aqueous extraction method. However, it was found that $p$-coumaric acid did not have significantly antioxidant activity compared with pyrogallol and or gallic acid even it was a major component when determined by HPLC. According to Rice-evan et al. [37] who reported that $p$-coumaric acid has one $\mathrm{OH}$ group at 4 in hydroxylbenzoic acid ring and expressed total antioxidant activity as $2.22 \pm 0.06 \mathrm{mM}$ TEAC while gallic acid has three $\mathrm{OH}$ groups at 3,4 and 5 
on hydroxylbenzoic ring and expressed total antioxidant activity as $3.01 \mathrm{mM}$ TEAC. This result confirmed that amount of $\mathrm{OH}$ groups played a major role in antioxidant property. Rutin and catechin contents in this experiment were a major component when determined by HPLC. Additionally, using blanching process increased amount of rutin and catechin up to 41.17 and $18.64 \%$, respectively. Furthermore, higher metal chelating activity of the blanched sample was in agreement with higher flavonoid content which expressed a great chelating property [38, 39]. The infusion of herbal tea making from blanched sample showed higher of all antioxidant activities except DPPH activity. This result confirmed that main bioactive compounds responded to high polar compounds due to aqueous extraction method.

Table 4. TPC, TFC and antioxidant activity of un-treated and blanched C. porrectum herbal tea infusion

\begin{tabular}{lcc}
\hline Antioxidant activities & \multicolumn{2}{c}{ C. porrectum herbal tea leaves extract } \\
\cline { 2 - 3 } & Un-treated & Blanched \\
\hline TPC & & \\
- mg GAE/g DM & $57.07 \pm 1.45^{\mathrm{bB}}$ & $66.25 \pm 0.89^{\mathrm{aB}}$ \\
- mg PYE/g DM & $40.50 \pm 0.87^{\mathrm{bA}}$ & $46.08 \pm 0.53^{\mathrm{aA}}$ \\
- mg $\boldsymbol{p}$-CAE/g DM & $79.75 \pm 1.71^{\mathrm{bC}}$ & $90.79 \pm 1.05^{\mathrm{aC}}$ \\
- mg TE/g DM & $227.27 \pm .5 .51^{\mathrm{bD}}$ & $262.21 \pm 3.38^{\mathrm{aD}}$ \\
DPPH & & \\
- mg GAE/g DM & & \\
- mg PYE/g DM & $56.06 \pm 2.90^{\mathrm{aA}}$ & $54.57 \pm 3.93^{\mathrm{aA}}$ \\
- mg $\boldsymbol{p}$-CAE/g DM & $74.08 \pm 4.56^{\mathrm{aA}}$ & $71.46 \pm 6.19^{\mathrm{aA}}$ \\
- mg TE/g DM & $1315.69 \pm 63.62^{\mathrm{aC}}$ & $1284.42 \pm 86.33^{\mathrm{aC}}$ \\
ABTS & $156.64 \pm 4.27^{\mathrm{aB}}$ & $155.83 \pm 5.79^{\mathrm{aB}}$ \\
- mg GAE/g DM & & \\
- mg PYE/g DM & $39.45 \pm 1.93^{\mathrm{bB}}$ & $42.79 \pm 0.40^{\mathrm{aB}}$ \\
- mg $\boldsymbol{p}$-CAE/g DM & $23.40 \pm 1.41^{\mathrm{bA}}$ & $25.74 \pm 0.29^{\mathrm{aA}}$ \\
- mg TE/g DM & $68.01 \pm 4.07^{\mathrm{bC}}$ & $74.29 \pm 0.84^{\mathrm{aC}}$ \\
& $176.75 \pm 8.34^{\mathrm{bD}}$ & $190.18 \pm 1.73^{\mathrm{aD}}$ \\
FRAP & & \\
- mg GAE/g DM & & \\
- mg PYE/g DM & & $69.84 \pm 1.52^{\mathrm{aB}}$ \\
- mg $\boldsymbol{p}$-CAE/g DM & & $36.01 \pm 0.20^{\mathrm{aA}}$ \\
- mg TE/g DM & $64.72 \pm 1.82^{\mathrm{bB}}$ & $349.44 \pm 2.53^{\mathrm{aD}}$ \\
& $33.32 \pm 0.63^{\mathrm{bA}}$ & $173.12 \pm 0.97^{\mathrm{aC}}$ \\
TFC (mg CE/g DM) & $317.24 \pm 7.94^{\mathrm{bD}}$ & \\
Iron chelating (mg EDTA /g DM) & $160.03 \pm 3.05^{\mathrm{bC}}$ & \\
\hline
\end{tabular}

a-b Means within a row with different letters are significantly difference $(\mathrm{p}<0.05)$.

A-D Means within a column of antioxidant activities (max activity to min activity) including DPPH, ABTS and FRAP activity with different letters are significantly difference $(\mathrm{p}<0.05)$.

TPC mean total extractable phenolic content; TFC mean total extractable flavonoid content; GAE mean gallic acid equivalent; PYE mean pyrogallol equivalent, $\boldsymbol{p}$-CAE mean $\boldsymbol{p}$-coumaric acid equivalent, TE mean Trolox equivalent and CE mean catechin equivalent. Values are represent as mean \pm standard deviation $(n=3)$.HPLC-profile 
From HPLC-PDA result, a significantly different profile of each sample was found in differently processing as shown in Figure $4 \mathrm{~B}$ and $4 \mathrm{C}$. The HPLC profiles of phenolic and flavonoid compound standards, in addition to the hydrolyzed extract of un-treated and blanched extract, were presented in Figure 4. It was found that 12 phenolics, including pyrogallol, gallic acid, protocatechuic acid, chlorogenic acid, $p$-coumaric acid, vanillic acid, cafeic acid, syringic acid, ferulic acid, tannic acid, cinnamic acid and rosmarinic acid and 6 flavonoid compounds, such as catechin, rutin, quercitrin, apigenin, quercetin and kaempferol were identified when using the retention time (RT) and peak pattern. The predominant phenolic acids were $p$-coumaric acid, pyrogallol, protocatechuic acid, tannic acid and gallic acid respectively. From the result, it was found that blanched extract provided a higher intensity of main predominant phenolic acids than those un-treated extract might be due to more extractable ability as discussed easier. These results were in agreement with the report of Cai et al. [40] who reported that phenolic compounds in the aqueous extract of $C$. cassia bark mainly contained cinnamic acid, protocatechuic acid, courmarin and tannins as major phenolics. Prasad et al. [41] reported that five species of Cinnamomum leaves including C. burmanni, C. cassia, C. pauciflorum, C. tamala and C. zeylanica extracted by 50\% ethanol contained 3 main flavonoids including quercetin, kaempferol and quercitrin. Moreover, $\mathrm{Li}$ et al. [42] and Yang et al. [43] reported that rutin was a main flavonoid compound found in $C$. zeylanicum and C. cassia.

According to HPLC profile results, the total extractable phenolic and flavonoid contents of blanched extract appeared to be greater than that of the un-treated extract. Among all of the identified phenolic acid and flavonoid constituents, there was indication that some of the phenolics including pyrogallol, gallic acid and cinnamic acid were higher in un-treated extract as 22.81 , 39.17 , and $58.87 \%$, respectively while $p$-coumaric acid, protocatechuic acid, caffeic acid and rutin were increased in blanched extract as 29.55, 7.56, 208.59, and 41.17\%, respectively (Table 5).

A higher content of gallic acid found in un-treated may be due to 2 main mechanisms; (1) hydrolyzed of tannin to tannic acid and gallic acid [44] and (2) these was no leaching effect into water particularly free, conjugated phenolics, when compared with blanching process [39, 45]. He et al [46] reported that cinnamic acid seemed to be decreased in blanched extract due to oxidation of cinnamic acid structure to $p$-coumaric acid, which was similar to this result confirmed by HPLC profile. In general, blanching process not only increased the predominant of phenolic acids such as $p$-coumaric acid and caffeic acid in the extract but also generated two higher intensity of unknown compounds than un-treated extract as shown in Figure $4 \mathrm{C}$ at retention time 17.28 and 20.17 which would be further studied. 

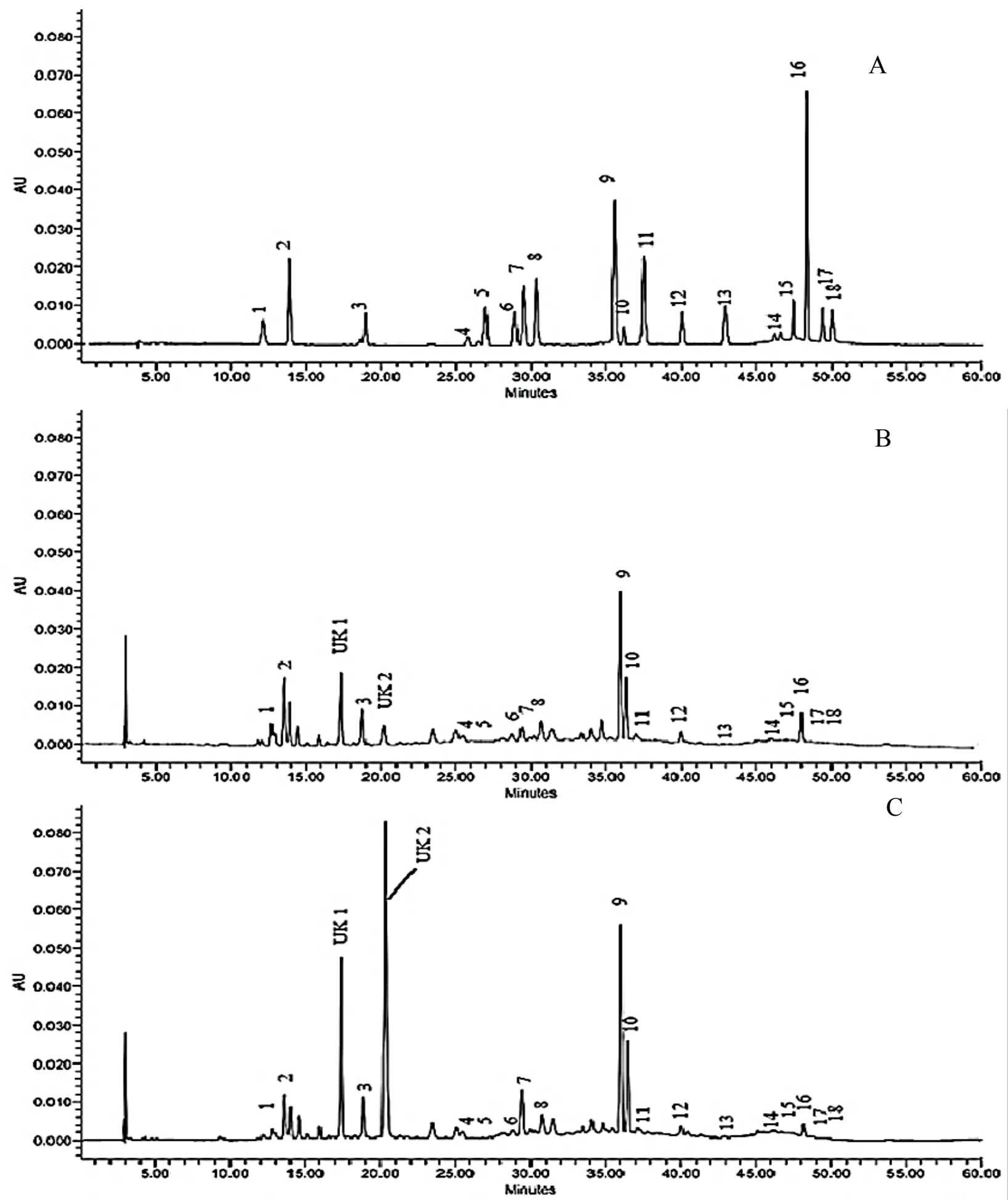

Figure 4. HPLC profile of phenolic compounds from standard HPLC (A) and extracted sample from un-treated (B) and water blanched (C) of hydrolyzed $C$. porrectum herbal tea infusion as freeze dried form with $6 \mathrm{~N} \mathrm{HCl}$ for $3 \mathrm{~h}$. Peak identification: 1, pyrogallol; 2, gallic acid; 3, protocatechuic acid; 4, catechin; 5, chlorogenic acid; 6, vanillic acid; 7, caffeic acid; 8, syringic acid; 9, p-coumaric acid; 10, rutin; 11, ferulic acid; 12, quercetrin; 13, rosmarinic acid; 14, tannic acid; 15, quercitin; 16, cinnamic acid; 17, apigenin and 18, kaempferol. 
Table 5. Phenolic acid and flavonoid composition of un-treated and blanched C. porrectum herbal tea extracts

\begin{tabular}{lccc}
\hline \multicolumn{4}{c}{$\begin{array}{c}\text { Phenolic acids and flavonoid } \\
\text { compounds }\end{array}$} \\
& $\begin{array}{c}\text { Un-treated } \\
\text { (mg/ 100 g of hydrolyzed extract) }\end{array}$ \\
\hline & Blanched & \% $^{\text {excreased }}$ inct $^{\mathrm{c}}$ & \\
\hline Pyrogallol & $114.33 \pm 0.04^{\mathrm{a}}$ & $88.24 \pm 3.20^{\mathrm{b}}$ & -22.81 \\
Gallic acid & $39.51 \pm 1.24^{\mathrm{a}}$ & $24.04 \pm 1.17^{\mathrm{b}}$ & -39.17 \\
Protocatechuic acid & $59.33 \pm 0.30^{\mathrm{b}}$ & $64.04 \pm 2.16^{\mathrm{a}}$ & 7.95 \\
Catechin & $33.78 \pm 4.33^{\mathrm{b}}$ & $40.08 \pm 0.38^{\mathrm{a}}$ & 18.63 \\
Chlorogenic acid & $1.15 \pm 0.23^{\mathrm{b}}$ & $1.85 \pm 0.40^{\mathrm{a}}$ & 60.87 \\
Vanillic acid & $10.90 \pm 0.35^{\mathrm{a}}$ & $10.16 \pm 0.88^{\mathrm{a}}$ & -6.83 \\
Caffeic acid & $12.81 \pm 0.83^{\mathrm{b}}$ & $39.56 \pm 1.85^{\mathrm{a}}$ & 208.98 \\
Syringic acid & $3.38 \pm 0.74^{\mathrm{a}}$ & $3.61 \pm 0.87^{\mathrm{a}}$ & 6.95 \\
p-coumaric acid & $444.33 \pm 1.77^{\mathrm{b}}$ & $575.63 \pm 3.00^{\mathrm{a}}$ & 29.55 \\
Rutin & $176.60 \pm 1.27^{\mathrm{b}}$ & $249.30 \pm 4.88^{\mathrm{a}}$ & 41.17 \\
Ferulic acid & $4.24 \pm 0.37^{\mathrm{a}}$ & $24.85 \pm 0.15^{\mathrm{b}}$ & -41.32 \\
Quercitrin & $1.08 \pm 0.33^{\mathrm{a}}$ & $15.14 \pm 0.57^{\mathrm{b}}$ & 46.09 \\
Romarinic acid & $1.04 \pm 0.45^{\mathrm{b}}$ & $2.18 \pm 0.11^{\mathrm{a}}$ & 108.61 \\
Tannic acid & $40.68 \pm 16.29^{\mathrm{a}}$ & $69.22 \pm 31.45^{\mathrm{a}}$ & 70.17 \\
Quercetin & $1.01 \pm 0.13^{\mathrm{a}}$ & $2.76 \pm 2.92^{\mathrm{a}}$ & 175.12 \\
Cinnamic acid & $6.09 \pm 0.14^{\mathrm{a}}$ & $2.51 \pm 0.13^{\mathrm{b}}$ & -58.87 \\
Apigenin & $3.29 \pm 3.21^{\mathrm{a}}$ & $3.13 \pm 4.43^{\mathrm{a}}$ & -4.86 \\
Kaempferol & $0.54 \pm 0.164^{\mathrm{a}}$ & $0.00 \pm 0.00^{\mathrm{b}}$ & -100.00 \\
\hline
\end{tabular}

${ }^{\mathrm{a}-\mathrm{b}}$ Means within a row with different letters are significantly different $(\mathrm{p}<0.05)$.

${ }^{c}$ Means \% increased calculated by phenolic contents of (blanching-control)/control x 100

\section{CONCLUSIONS}

Pre-treatment by blanching before drying process maintained color quality related to high chlorophyll contents. Using blanching process increased not only pore size of dried leaves but also all TPC, TFC extractability, and antioxidant activities, including ABTS, FRAP, and metal chelating activity. Protocatechuic acid, caffeic acid, $p$-coumaric acid, and rutin in blanched extract were higher than that of un-treated extract. Two more unknown compounds with high intensity of both un-blanched and blanched herbal tea particularly in blanched sample would be needed for further study.

List of Abbreviations: Cinnamomum porrectum, total extractable phenolic content, total extractable flavonoid content, antioxidant activities, blanching processing, chlorophyll content, phenolic profile

Competing interest: None to declare. 


\section{Author's contributions:}

Phornthip Saetan, BSc- PhD is a Food Technologist and performed all of the laboratory work for the study and provided statistical analysis and assisted in writing the manuscript.

Worapong Usawakesmanee, $\mathrm{PhD}$ is a Food Technologist. He is principal investigator for this study providing oversight and contributing fundamental conceptualization for the research, writing the grant proposal and manuscript.

Sunisa Siripongvutikorn, $\mathrm{PhD}$ is an Assistant Professor of Food Technology. She initiated and to accelerated the development and (subsequent) production of the intervention drink. She also contributed in the study design and assisted in writing the manuscript

Financial sponsor: The financial support of the Grant-in-aid for dissertation from Graduate School, Prince of Songkla University, Thailand.

Acknowledgements: The authors would like to thank the Graduate School of Prince of Songkla University, Thailand, for the financial support.

\section{REFERENCES}

1. Seeram NP, Aviram M, Zhang Y, Henning SM, Feng L, Dreher M, Heber D.: Comparison of antioxidant potency of commonly consumed polyphenol-rich beverages in the United States. Agric Food Chem 2008, 56 (4): 1415-1422.

2. Lin KH, Yeh SY, Lin MY, Shih MC, Yang KT, Hwang SY.: Major chemotypes and antioxidative activity of the leaf essential oils of Cinnamomum osmophloeum Kaneh. from a clonal orchard. Food Chem 2007, 105 (1): 133-139.

3. Gill GS, Kumar A, Agarwal R.: Monitoring and grading of tea by computer vision- A review. Food Eng 2011, 106: 13-19.

4. Lee R, Balick MJ.: Sweet wood-cinnamon and its importance as a spice and medicine. J. Health Sci 2005, 1 (1): 61-64.

5. Mathew S, Abraham TE.: In vitro antioxidant activity and scavenging effects of Cinnamomum verum leaf extract assayed by different methodologies. Food Chem Toxicol 2006, 44 (2): 198-206.

6. Mathew S, Abraham TE.: Studies on the antioxidant activities of cinnamon (Cinnamomum verum) bark extracts, through various in vitro models. Food Chem 2006, 94 (4): 520-528.

7. Pukdeekumjorn $\mathrm{P}$, Reuangnoo $\mathrm{S}$, Panthong $\mathrm{S}$, Itharat $\mathrm{A} .:$ In vitro antioxidant, antiinflammatory and anyimicrobial activities of Cinnamomum porrectum wood (Thep-TaRo). Sci-Health 2012, 019: 1-6.

8. Jia Q, Liu X, Wua X, Wang R, Lia Y, Hung C.: Hypoglycemic activity of a polyphenolic oligomer-rich extract of Cinnamomum parthenoxylon bark in normal and streptozotocininduced diabetic rats. Phytomed 2009, 16 (8): 744-750.

9. Buru AS, Pichika MR, Neela V, Mohandas K.: In vitro antibacterial effects of Cinnamomum extracts on common bacteria found in wound infections with emphasis on methicillin-resistant Staphylococcus aureus. J. Ethnopharmacol 2014, 153: 587-595.

10. AOAC: Association of Official Analytical Chemists: Official Method of Analysis: Official Method of Analysis: Washington D.C. Press; 2000. 
11. AOAC: Chlorophyll in plants: In Official Methods of Analysis of the AOAC. Edited by Helrich K. Washington D.C. Press; 1990: 62-63.

12. Wu HC, Chen HM, Shiau CY.: Free amino acid and peptide as related to antioxiant properties in protein hydrolysates of mackerel (Scomber austriasicus). Food Res Int 2003, 36: 949-957.

13. Arnao MB, Cano A, Alcolea JF, Acosta M.: Estimation of free radical-quenching activity of leaf pigment extracts. Phytochem Anal 2001, 2: 138-143.

14. Benzie IFF, Strain JJ.: The ferric reducing ability of plasma (FRAP) as a measure of antioxidant power the FRAP assay. Anal Biochem1996, 239: 70-76.

15. Boyer LC, McCleary CJ.: Superoxide ion as a primary reductant in ascorbate-mediated ferritin iron release. Free Rad Bio Med 1987, 3: 389-395.

16. Song JY, An GH, Kim CJ.: Color, texture, nutrient contents, and sensory values of vegetable soybeans (Glycine $\max$ (L.) Merrill) as affected by blanching. Food Chem 2003, 83: 69-74.

17. Cheftel JC, Cuq J, Lorient D: Amino acids, peptides, and proteins. In Food chemistry. 2nd edition. Edited by Fennema OR. New York: Marcel Dekker; 1985: 245-369.

18. Dugo G, Lapera L, Turco VL, Palmieri RM, Saitta M.: Effect of boiling and peeling on manganese content of some vegetables determined by derivative anodic stripping chronopotentiometry (dASCP). Food Chem 2005, 93 (4), 703-711.

19. Lewu MN, Adebola PO, Afolagan AJ.: Effect of cooking on the mineral contents and antinutritional factors in seven accessions of Colocasia esculenta (L.) Schott growing in South Afric. J Food Compos Anal 2010, 23(5), 389-393.

20. Sila DN, Buggenhout SV, Duvetter T, Fraeye I, Roeck AD, Loey AV, Hendrickx M.: Pectins in processed fruits and vegetables: Part II-Structure-Function Relationships. Compr Rev Food Sci Food Saf 2009, 8: 86-104.

21. Ando Y, Maeda Y, Mizutani K, Wakatsuki N, Hagiwara S, Nabetani H.: Impact of blanching and freeze-thaw pre-treatment on drying rate of carrot roots in relation to changes in cell membrane function and cell wall structure. LWT- Food Sci Technol 2016, 71: 40-46.

22. Stamatopoulos K, Katsoyannos E, Chatzilazarou A, Konteles SJ.: Improvement of oleuropein extractability by optimizing steam blanching process as pre-treatment of olive leaf extraction via response surface methodology. Food Chem 2016, 133 (2): 344-351.

23. Deylami MZ, Rahman RA, Tan CP, Bakar J, Olusegun.: Effect of blanching on enzyme activity, color changes, anthocyanin stability and extractability of mangosteen pericarp: A kinetic study. Food Eng 2016, 178: 12-19.

24. Acosta-Estrada BA, Gutiérrez-Uribe JA, Serna-Saldívar SO.: Bound phenolics in foods, a review. Food Chem 2014, 152: 46-55.

25. Erbay Z, Icier F.: Optimization of hot air drying of olive leaves using response surface methodology. Food Eng 2009, 91: 533-541.

26. Ozilgen M, Ozdemir M.: A review on grain and nut deterioration and design of the dryers for safe storage with special reference to Turkish hazelnuts. Crit Rev Food Sci Nutr 2001, 41: 95-132. 
27. Tijkens LMM, Barringer SA, Biekman ESA.: Modelling the effect of $\mathrm{pH}$ on the colour degradation of blanched broccoli. Innov Food Sci Emerg Technol 2001, 2: 315-322.

28. Erge HS, Karadeniz F, Koca N, Soyer Y.: Effect of heat treatment on chlorophyll degradation and colour loss in green peas. GIDA 2008, 33(5): 225 - 233.

29. Schwartz SJ, Lorenzo TV.: Chlorophyll stability during continuous aseptic processing and storage. Food Sci 1991, 56: 1059-1062.

30. Cui Z, Xu SY, Sun DW.: Effect of microwave-vacuum drying on the carotenoids retention of carrot slices and chlorophyll retention of Chinese chive leaves. Dry Technol 2004, 22: 563-575

31. deMan FM: Principles of food chemistry: Van Nostrand Reinhold: New York; 1990.

32. Gupte SM, Francis FJ.: Effect of $\mathrm{pH}$ adjustment high-temperature short-time processing on color and pigment retention in spinach puree. Food Technol 1964, 18: 1645-1658.

33. Nicoletti I, Martini D, De Rossi A, Taddei F, D’Egidio MG, Corradini D.: Identification and quantification of soluble free, soluble conjugated, and insoluble bound phenolic acids in durum wheat (Triticum turgidum L. var. durum) and derived products by RP-HPLC on a semimicro separation scale. J. Agric Food Chem 2013, 61: 11800-11807.

34. Chan CL, Gan RY, Corke H.: The phenolic composition and antioxidant capacity of soluble and bound extracts in selected dietary spices and medicinal herbs. Int J Food Sci Technol 2016, 51: 565-573.

35. Zhang Y, Wang L, Yao Y, Yan J, He ZH.: Phenolic acid profiles of Chinese wheat cultivars. J. Cereal Sci 2012, 56: 629-635.

36. Blainski A, Lopes GC, Mello JCP.: Application and analysis of the folin ciocalteu method for the determination of the total phenolic content from Limonium Brasiliense L. Molecules 2013, 18: 6852-6865.

37. Rice-Evans CA, Miller JM, Paganga G.: Structure-antioxidant activity relationship of flavonoids and phenolic acids. Free Rad Biol Med 1996, 20: 933-956.

38. Pietta PG.: Flavonoids as antioxidants. J Nat Prod 2000, 63: 1035-1042.

39. Heim, Tagliaferro, Bobilya.: Flavonoid antioxidants: Chemistry, metabolism and structure - activity relationships. J Nutr Biochem 2002, 13: 572- 584.

40. Cai YZ, Luo Q, Sun M, Corkem H.: Antioxidant capacity and phenolic compounds of 112 traditional Chinese medicinal plants associated with anticancer. Life Sci 2004, 74: 2157 2184.

41. Prasad KN, Yang B, Dong X, Jiang G, Zhang H, Xie H, Jiang Y.: Flavonoid contents and antioxidant activities from Cinnamomum species. Innov Food Sci Emerg Technol 2009, 10: 627-632.

42. Li HB, Wong C C, Cheng KW, Chen F.: Antioxidant properties in vitro and total phenolic contents in methanol extracts from medicinal plants. LWT-Food Sci Technol 2008, 41: 385-390.

43. Yang CH, Li RX, Chuang LY.: Antioxidant activity of various parts of Cinnamomum cassia extracted with different extraction methods. Molecules 2012, 17: 7294-7304.

44. Hagerman AE, Carlson DM. Biological responses to dietary tannins and other polyphenols. J Agric Food Chem 1998, 28, 947-952. 
45. Lin L, Lei F, Sun DW, Dong Y, Yang B, Zhao M.: Thermal inactivation kinetics of Rabdosia serra (Maxim.) Hara leaf peroxidase and polyphenol oxidase and comparative evaluation of drying methods on leaf phenolic profile and bioactivities. Food Chem 2012, 134 (4): 2021-2029.

46. He M, Tian H, Luo X, Qi X, Chen S.: Molecular Progress in Research on Fruit Astringency. Molecules 2015, 20: 1434-1451.

47. Ozturk B, Seyhan F, Ozdemir IS, Karadeniz B, Bahar B, Ertas E, Ilgaz S.: Change of enzyme activity and quality during the processing of Turkish green tea. LWT - Food Sci Technol 2016, 65: 318-324. 